Jaydev A. Jani and Peter Schreiner*

\title{
Authorship and Authority in the Sanskrit Literary Tradition of the Swaminarayana Movement: Śikșāpatrī and Satsañgijīvanam
}

DOI 10.1515/asia-2015-0053

\begin{abstract}
This paper presents what the Satsangijīvanam, a text by Śatānanda-Muni about the life and teachings of Sahajānanda, the founder of the Swaminarayana Movement, in two different passages reports about the authorship of the Sikșāpatrī. It would appear that Swaminarayana (the name by which the founder came to be known) wrote the Śikṣāpatrī well before Śatānanda produced the version included in the Satsangijivanam. What the Satsangijivanam tells us about the authorship and the process of transmission of the Satsangijivanam itself complicates the evaluation of the Satsangijivanam as a historical document. Yet, the fact that the text shows that Swaminarayana may not be the author of the currently known Śikșāpatrī invites reflection about the function of texts in the traditional selfperception and in the history of the Swaminarayana Movement.
\end{abstract}

Keywords: Swaminarayana movement, Hinduism, Śikṣāpatrī, Satsañgijīvanam, authorship of translations

\section{Introduction}

The term authorship as used in the title refers to the writing or more generally to the process of production and attribution of texts. The problem and concept of authorship can, however, be complicated in case of multiple authorship or of authorized revision (translation included) and is thereby linked to the concept of authority as an instance before and around the actual text and its wording. If a politician employs ghost writers to formulate his speeches, he or she is not the author of the text, but the politician authorizes it. Or if the Koran was dictated to Mohammed by a heavenly voice, then the prophet may not be considered the author. If Purānas are attributed to Vyāsa we do not have an author but only the

\footnotetext{
*Corresponding author: Peter Schreiner, University of Zürich, Department of Indian Studies, Rämistr. 59, CH-8001, Zürich. E-mail: peter.schreiner@aoi.uzh.ch Jaydev A. Jani, Department of Sanskrit, M. S. University of Baroda, Vadodara, India. E-mail: jaydevj@yahoo.com
} 
authority linked to a name and to a textual tradition. And if later poets use "Kabir" as a name-seal in their verses they appropriate and identify with an author and his literary technique and message.

The concept of "authority" is among the tools to describe and classify and compare the role of texts in religious traditions. In this paper we shall examine what two texts from the Sanskrit literary tradition of the Swaminarayana Movement, the Śikșāpatrī and the Satsangijīvanam, tell us about their authorship. Our approach is philological and it is text-immanent; its textual analysis is only concerned with the Satsangijīvanam and the Śikṣāpatrī. Thus, we shall not expand on theoretical discussions on concepts like authorship, authority, textuality, canonization, etc. Our method and perspective obviously may also differ from an emic perspective. ${ }^{1}$

The Swaminarayana Movement derives its name from the name of its founder (1781-1830) who was born as Ghanaśyāma in a Brahmin family in Chapiya near Ayodhya and left home at the age of 11 (after the parents' death). He wandered through India known by the name Nillakanthha until he was initiated by one Swami Rāmānanda (1739-1802) to become Swami Sahajānanda. Swami Rāmānanda shortly afterwards (in 1801) made the young swami his successor. To his followers Swami Sahajānanda is Swaminarayana, an embodiment of Kṛ̣ṇa, the personal absolute. His movement spread in Gujarat and was organized in two dioceses (Vadtal and Ahmedabad) under the guidance of two ācāryas (the founder's nephews, their function being hereditary among their descendants). A new branch, the B.A.P.S. (Bocāsaṇavāsī Akṣara Puruṣottama Saṃsthā), originated in 1907 (by separation from Vaḍtal) and has become the internationally perhaps most

1 This contribution aims at presenting the textual basis for the theoretical problems of a specific case of interlocked multiple authorship of a holy text. Its scope is that of a case study; it is neither an analysis of the Śikșāpatrī nor a comprehensive analysis of the Satsangijīivanam. The paper also does not include any comparative approach even though certain parallels and differences in other religions or traditions clearly invite or even demand comparison. These limitations explain the deliberate limitation of the bibliography. The evidence of the Satsangijīvanam may have raised theoretical reflections in the exegesis of the texts and may have been dealt with in the commentarial literature of the Movement's branches, but such reflections and exegesis do also not fall within the scope of the paper. In order to contextualize this paper a study of the role of texts in general in the Swaminarayana Movement, including the study of the selection of quasi-canonical authoritative texts and of the frequency of references to and quotations from these texts, further a study of the importance of public or private recitation of texts, and of the function of textualized (originally oral) instructions by the founder in religious practice would all be required and presupposed. The question whether and how the Swaminarayana Movement could be considered "a religion of the book" addresses the wider horizon of the title question. 
visible representative of the Swaminarayana Sampradāya. ${ }^{2}$ The movement is committed to religious reform (especially of Kaula practices current at the time of Swaminarayana), but at the same time propagates the conservation of traditional values and practices. It is a movement with particular, perhaps unique and characteristic traits in its theological and philosophical thinking.

Śikṣāpatrī and Satsangijīvanam are two important texts in the Sanskrit literary tradition of the Swaminarayana Movement. The Śikṣāpatrī, attributed to Swaminarayana himself, summarizes the rules of conduct for his followers and has been considered as a catechism and Holy Scripture in the Swaminarayana Movement. It is a Sanskrit text in 212 verses. In the second verse the author identifies himself: "I, Sahajānandasvāmī, write this 'letter of instructions' while staying in Vṛttālaya (i. e., Vaḍtal) to all my followers living in different regions (or countries).” In the conclusion the followers are admonished to live in conformance to these instructions and to read this text daily; those who are illiterate should listen to its recitation or at least venerate it (probably as a 'book' or manuscript) in the conviction that "my word is a form of mine" (madrūpam iti madvān̄i mānyeyam, v. 209). ${ }^{3}$

To judge from the availability of printed editions and commentaries, this text generally seems to be considered as an independent work. ${ }^{4}$ This aspect of the reception history is likely to have been established by Satānanda who not only incorporated the Śikṣāpatrī in the Satsanigijīvanam, but wrote an extensive Sanskrit commentary on the Śikșāpatrī. In spite of the fact that the other primary scriptural source besides the Sikșāpatrī attributed to Swaminarayana, the Vacanāmṛta (a collection of speeches given by Swaminarayana to his followers and collected

2 For background information about the history of the movement and its teachings see Williams 1984.

3 The verses can roughly be grouped according to subject matter:

1-10 Origin and intention of the text;

11-122 Rules of conduct applicable to everybody;

123-134 Dharma of the ācāryas and their wives;

135-156 Householders;

157-158 Kings;

159-174 Conduct of women (married women, widows);

175-187 Instructions concerning celibates;

188-196 Instructions concerning sādhus;

197-202 Dharma common to celibates and sādhus;

203-212 Conclusion.

4 The English as well as the Gujarati translations which the authors happened to see - and we admittedly made no effort to establish a publication history or a bibliography of editions - include the Sanskrit verses. 
and edited by monks close to him), is in Gujarati, Swaminarayana is generally supposed to be the author of these Sanskrit verses. The impression of the Siikșāpatrī as an independent text written by Swaminarayana, however, is questioned by what the Satsangijivanam itself tells about its origin. Thus, only when, in the course of our research on the literary Sanskrit tradition of the Swaminarayana Movement, ${ }^{5}$ we came across the Śikșāpatrī as a chapter in the Satsañgijīvanam, the problem of authorship had to be considered or reconsidered. ${ }^{6}$

The reputation and importance of the Śikșāpatrī as a Holy Scripture is not extended to the Satsangijīvanam (abbreviated SSJ). The latter is a large text in five parts (comprising 319 chapters and 16,493 verses) narrating Swaminarayana's biography and presenting his teachings. ${ }^{7}$ It was commissioned by the founder

5 See above, Acknowledgements.

6 That the discovery of the Śikșāpatrī in the Satsangijīvanam came as a surprise only reflects the authors' ignorance; very likely any insider interested in and informed about the history of the Movement could have told us; but in fact, nobody did.

7 The size of the text makes it difficult to summarize its outline and content. The first part (prakarana) introduces the dialogue setting and Śatānanda as author; it speaks about Swaminarayana's parents and about the miseries caused by the predominance of adharma as cause for Swaminarayana's manifestation. Chapters 1,11-16 relate the parents' meeting with Rāmānanda, Swaminarayana's teacher, 17-22 narrate their pilgrimage to Vụndāvana and Swaminarayana's birth. 1,23-36 concern his childhood and training; 1,37-42 narrate the parents' death and the child's departure from home. 1,43-50 summarize his wanderings and victories over demons and other adversaries until the arrival in Loj. 1,51-60 concern the meeting with the followers of Swami Rāmānanda and the initiation by the Swami until the latters death. The second part (52 chapters) narrates about Swaminarayana's travels through Gujarat and about his winning followers and the support of different "kings" through his instructions. Part 3 consists largely of descriptions of celebrations: 3,4-22 food-festival; 3,23-45 Prabodhini-festival; 3,46-64 Swing-festival in Vụttālaya. Part 4 summarizes Swaminarayana’s instruction and regulations concerning the recitation of Purāṇas (4,1-9), the celebration of the Janmāșțamì-festival in Sārañgapura (4,10-12), the visit to Kāryāyaṇa and Nāgațańka (4,13-19), the celebration of the Swing-festival in Pañcāla and the return to Durgapura (4,20-23); chapter 4,24 relates about Swaminarayana's intentions concerning the organization of the movement and his succession, viz., through construction of temples (4,25-33, glorifying Vṛttālaya in particular), appointment of ācāryas (narrated in 4,40), and the writing of the Śikṣāpatrī, narrated in 4,44. There is a report about a theological discussion about the meaning of triyuga $(4,34-38)$ and there are detailed instructions about different kinds of initiation (4,46-54); the next sections regulate the celebration of festivals (4,55-61) and the conduct of monks (4,62-67); part 4 ends with an exposition on cosmology, largely along Sāmphya lines (4,68-73). Part 5 begins with an extensive section with instructions about dharma (5,1-29, 30-37 concerning women, 38-54 concerning stages of life with 5,41-48 on expiation); 5,56-65 is an exposition on yoga. 5,67 describes the power of the images installed by Swaminarayana, chapter 68 narrates about his demise, 69 instructs about the Harijayanti-vow, i. e., the observation of Swaminarayana's birthday. The work concludes with a list of its contents $(5,70)$. 
and written during his life-time by Swami Śatānanda. It also contains details about the writing of the Śikṣāpatrī and its incorporation in the Satsangijīvanam which invite reflection about the applicability of the concept of authorship with regard to the Sanskrit text of the Sikṣāpatrī.

The problem to be studied in the following as a historical question can be summarized very concisely: The Sikșāpatrī is attributed to Swaminarayana as its author. The author of the Satsanigijīvanam is Śatānanda-Muni. At the same time, however, the authoritative version of the Sikșāpatrī is contained in the Satsangijivanam and could thus also be considered to have been authored by Śatānanda.

We restrict ourselves to the presentation of three passages from the Satsangijīvanam on the origin of Satsangijīvanam and of the Śikṣāpatrī. The first deals with the authorship and characteristics of the Satsangijivanam itself; the second and third are the two episodes in the Satsangijīvanam which report about the origin of the Sikșāpatrī. The passages address problems concerning claims of authorship, including the possibility of joint authorship, delegated authorship and (marginally) the problem of how translation from one language to another affects authorship. This will lead, in the conclusion, to questions and prospects for further research, both historical and conceptual. ${ }^{8}$

\section{The Satsangijīvanam on the Satsanigijīvanam}

Most of what the Satsangijivanam tells us about its authorship and process of transmission is contained in its first three chapters. They mention many details about the text of which they form the beginning.

Verses 17-22 of the first chapter ${ }^{9}$ identify the Satsangijivanam as a work by Śatānanda. As the essence of all Vedas, it propounds the dharma of absolute devotion (aikāntikadharma), and boasts the ability to cause liberation from the

8 The authors do not lay claim to the commitment and perspective with which insiders of the movement might approach these questions. One would have to take into account that the different branches of the movement might view the historical information contained in the Satsangijivanam with conflicting loyalties. We are not aware of initiatives based on an "ecumenical" interest in the text of the Satsangijivanam among the branches of the movement.

9 I.e. Satsangijīvanam 1,1.17-22. Full references to the text consist of three parts, representing part, chapter and verse(s). The Sanskrit original of summarized or translated passages is given in the footnotes. The digitalization of the Satsangijivanam in Sanskrit and an English summary of its contents were produced by the project referred to in footnote 5 and the Acknowledgements. 
bonds of existence. It is like a boat and describes the life of the Son of Dharma, i. e., Swaminarayana. Only the good derive from it merit and freedom from evil. The last two verses praise the work as an ornament of its poet. ${ }^{10}$

Since Satānanda is mentioned as the author, it may be assumed that it is he who is speaking. However, the first chapter then presents a dialogue situation which presupposes the existence of the finished work, since the dialogue belongs to the text recited in that dialogue by a Suvrata to a king; a Satsangijīvanam is inserted into a Satsangijīvanam. ${ }^{11}$ The request by the king and Suvrata's recitation are part of the history of what happened with the completed Satsangijivanam (cf. 1,3.49-50). The work was heard rather than read. If one accepts Satānanda as its author, it must be Śatānanda who invented the recitation of his work by Suvrata, perhaps as part of making his work conform to purānic conventions. At the time of writing the frame story, the recitation of the finished work would be a future event. Hence, in a perspective of literary analysis, it is clearly an invented event or fiction.

10 śrīmacchatānandakṛte 'tra ramye | saṃdarbhasāre 'khilavedasāraḥ | suspaștam aikāntikadharma uktah | syād yena sadyo bhavapāsamukțị || 1,1.17 | sākșād dharau sakalalokagurau rasāyā | antarhite nanu mumukșujanaikabandhau | nistāraṇāya laghu saṃsrtisāgarasya | naukedam eva bhuvi mānavadehabhājām || 1,1.18 |

līlāraso hi sakalo 'mritadivyamūrteh | svecchānarākṛtidhṛto bhuvi dharmasūnoḥ| satsanginām paramajīvanam asty ato 'sau | samyyan nirūpita iheti sa pīyatāṃ taịh || 1,1.19 | etat puṇam alaṃpavitram amalaṃ saddharmaśāstram param | dharmajñānavirāgabhakti nibhṛtaṃ sevyaṃ satāṃ nityadā | pāpaughapraśamaṃ ṇ̛nām kalimalaprakṣālanaṃ sarvathā | jādyadhvāntanivāraṇaṃ sukṛtibhị̣ samprōāpyate netaraih || 1,1.20 | sakaladharmavinirnayam añjasā | sakalaśāstramatabhramavāraṇam | sakalavāñnchitapūraṇam uttamam | sakalalokamanah śrutirañjanam || 1,1.21 |

vividhasaṃśayaśalyasamuddharaṃ | śravañamātrata eva kubuddhihṛt | madanakopamukhāribhayāpaham | jayati śāstram idạ̣ kavibhūṣaṇam || 1,1.22 |

11 The dialogue setting never gets completely forgotten since "Suvrata said" is frequently inserted and the narration time and again includes vocatives addressed to the listening king. 
The other possibility is that Satānanda is not the author of the frame story. The later redactor would be a second author and may perhaps have been Suvrata or somebody in the service of the king, possibly Śatānanda at a later time in his life, i. e., after the recitation. The second author would have added this frame story to an earlier version of the Satsangijīvanam. ${ }^{12}$ If outline and content of the Satsangijivanam suggest an editorial addition in the case of the frame story, one cannot be certain about which words, lines or chapters stem from Satānanda, and which from the secondary author or authors. Secondary authorship could also have occurred several times; such is difficult to discover and to identify unless there are manuscripts from different hands.

Thus, from the point of view of authorship the interpretation of what the text says becomes complex, since the narrative is not presented by the author; rather it is embedded in a dialogue between a king and Suvrata, one of Śatānanda's disciples who tells us that he heard the work several times. If Suvrata is a historical personality and if the recitation is also historical, we arrive at having a Satsangijīvanam within a Satsangijīvanam. Of which one is Satānanda the author?

According to Suvrata, only the passages recited to the king are by Satānanda, while the frame story would have to be added by somebody else who cannot have been Suvrata. If, on the other hand, Satānanda is the author also of the frame story, he would have included a future ${ }^{13}$ (if Suvrata's recitation did actually take place) or a fictitious and invented event; but as a reader and historian one is then confronted with the question of how to distinguish historical fact from narrative embellishment, fantasy or fiction.

To continue the summary, chapter 2 tells about Śatānanda's qualifications and sources. The non-identified narrator reports the kings questions and his inquiry about Śatānanda-Muni and introduces Suvrata's report. Śatānanda stems from Mithilā. He knows the Vedas, Sāastras, Purāṇas and Pañcarātra and he regularly reads the Bhāgavatapurāna. He learns from this text that NaraNārāyana resides in India and therefore goes on a pilgrimage to Badarikā where he worships Nara-Nārāyaṇa. He recites the $10^{\text {th }}$ skandha of the Bhāgavatapurāṇa for six months. Eventually he is granted the Lord's vision. Satānanda prostrates and praises the Lord with a hymn.

12 These are the kind of processes to be expected in a Purāṇa.

13 For a text which follows the conventions of a literary genre that does not want or need to be 'historical' (e. g. a Purāṇa, hagiography, etc.) the text-critical method cannot do justice neither to the author's intentions nor to the expectations of the audience. 
The words of this hymn form the beginning of chapter 3. Satānanda is here talking about himself in third person. Nara-Nārāyaṇa tells Śatānanda (1,3.15-19) about his birth in Uttara-Kosala and that he presently lives in West-Pañcāla; he prophesies that Satānanda will create a book about his deeds. ${ }^{14}$ The book referred to of course is the Satsangijīvanam. Authorship of the Satsañgijīvanam is attributed to a divine boon.

The episode continues by narrating (1,3.34-41) that a little later Satānanda achieves meditative trance even without practice of Yoga and has a vision of the Lord of Badarī; he is shown the Lord's heavenly abodes (Akșara-Dhāman, Goloka, Vaikunthha, Śvetadvipa) and he sees how his parents manifested themselves and he beholds the men and women who are his devotees. Satānanda receives omniscience about past, present and future. Next (1,3.44-46) Hari grants a boon and orders Satānanda to go with him to Durgapattanam where he will have a temple built for Rādhā-Kṛṣna; there Śatānanda will create a work (śāstra) about his experiences. The next verses $(1,3.47-48)$ relate that Śatānanda acted accordingly and produced the Dharmaśāstra Satsañgijīvanam in the temple of Śrīgopīnātha. The chapter ends $(1,3.51)$ with an appeal to listen to the work. ${ }^{15}$

14 ity uktavantam bhagavāṃs tam uvāca mahāmatim |

brahmaṃs tvayā vyavasitam saṃyag etan mumukșuṇā || $1,3.15$ |

kiṃtv ahaṃ sāmpratam bhūmau kosaleșūttareșv iha |

jāto 'smi dharmato bhaktau harināmnā hi viśrutah || 1,3.16 |

varte paścimapañcāladeśe durgapure 'dhunā

so 'ham tvām antike svasya rakṣișyāmi na saṃśayaḥ || 1,3.17 |

madīyaguṇagānecchā vartate tava hṛdy ataḥ |

tasya me tvaṃ caritrāṇām granthakartā bhaviṣyasi || 1,3.18 |

so 'ham pūrnam karișyāmi tvadvāñnchitam atas tvayā |

so 'nveșya prāpya ity uktvā bhagavān sa tiro dadhe || 1,3.19 |

Note on the places mentioned in v. 17: Paścimapañcāla is the Ahmedabad Region; Durgapura (also called Durgapattana) is Gaḍhaḍā.

15 kālenālpena ca hareh krpayā tasya saddhiyaḥ | samādhisiddhir așțāngayogābhyāsaṃ vinābhavat || 1,3.34 | dhyāyaṃs tạ̣ hṛdi so 'drākșīd prāgdṛșțam badarīśvaram | kṣaṇānte 'ntarhitaḥ so 'tha yathā saudāmanī divi || 1,3.35 | jyotirmaye 'kṣare dhāmni sthitam taṃ kṛ̦ṇam aikșata | samagraiśvaryasaṃpannaṃ sapārșadaparigraham || 1,3.36 | golokam atha vaikunțham śvetadvīpādi dhāma yat | tadaikṣayat sahaiśvaryam haris tasmā alaukikam || 1,3.37 | yathā svayam cāvir āsid dharmo bhaktis tatharșayah | teșām rupaṃ yathā pūrvam atratyaṃ cāpy abūbudhat || 1,3.38 | svasya bhaktāś ca ye bhūmau purușā yoșitas tathā | api teșām ubhe rūpe tasmai harir ajijñapat || 1,3.39 | 
The actual writing at this point is a future event which is related in part 5 of the Satsangijīvanam (5,49-50). As early as here it is said that after Swaminarayana's disappearance from this world Satānanda recited it several times in front of Suvrata and others.

By writing about the events in Swaminarayana's life, Satānanda acts as a chronicler and historian. For one part of the reported events he was an eye witness. But what were his sources for events which happened before Śatānanda joined and followed Swaminarayana? The narrator seems to anticipate the historian's dilemma. If Śatānanda is to write about events of the past which he has not experienced he needs to have access to the missing information. By being granted omniscience Satānanda receives knowledge also about the past, that is to say, access to the historical information that he will need to write the book.

The text does not mention, when exactly in Satānanda's life Swaminarayana's prophesy - during the visit and vision at Badarika - had happened. Part 2 of the

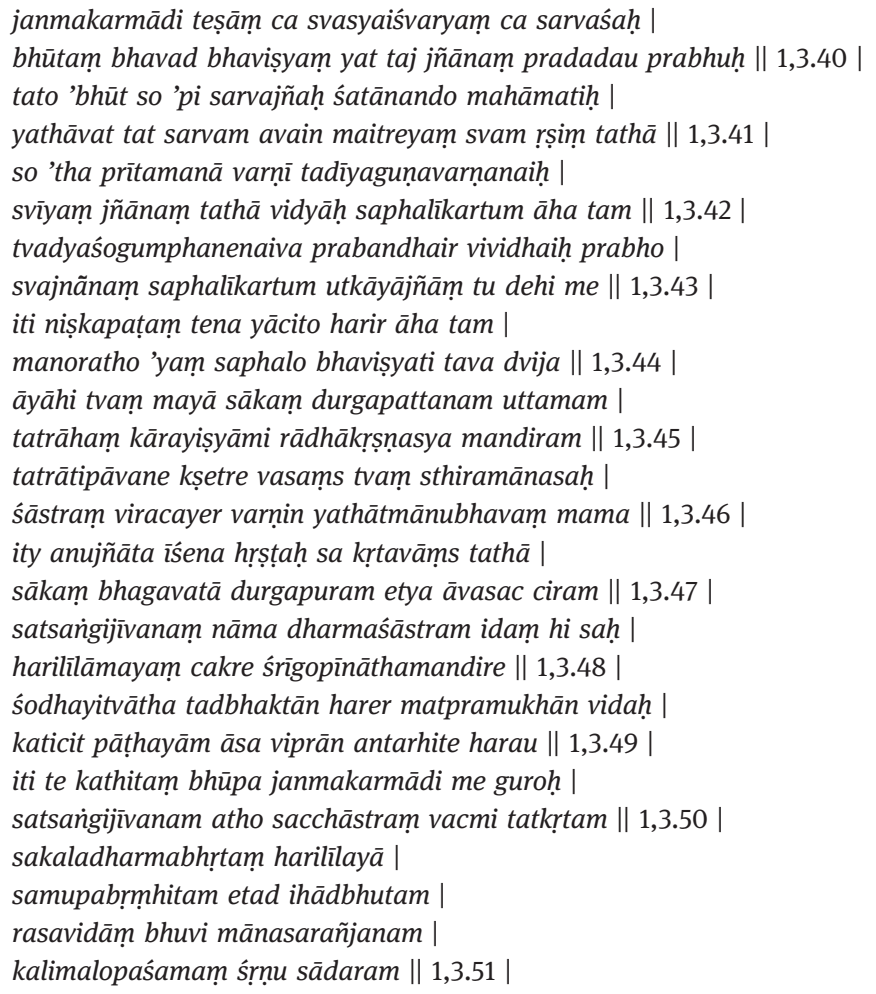


Satsangijīvanam however mentions that the first meeting of Satānanda ${ }^{16}$ with Swaminarayana in Darbhavatī took place in 1814 A.D. This means that all the events prior to this date are known to Satānanda by hearsay. Satānanda became Swaminarayana's disciple 14 years before the composition of the Satsangijivanam in 1828. With Swaminarayana's boon in mind he could have consciously and systematically collected information during these 14 years.

Śatānanda is mentioned again as the author of the Satsangijīvanam in part 3. ${ }^{17}$ At the beginning (ch. 3,2) it deals with arrangements for serving Swaminarayana. The list includes the services of Śatānanda-Muni as editor (śodhayām āsa) of eight sacred texts composed by Śī-Hari ${ }^{18}$ and as the author of the Satsangijīvanam (see 3,2.29-30; 3,2.51b). The Satsangijivanam is distinguished from the class of these eight works by not being attributed to Swaminarayana. The eight works are not identified by title; Śatānanda again refers to himself in third person and the Sanskrit verb used to express Swaminarayana's literary activity is a causative form: "The knowledgeable Śatānanda carefully redacted the eight true Sāastras which Hari had caused to be written (lekhitāni) earlier." $(3,2.29)^{19}$

\section{The episode of Swaminarayana writing the Śikșāpatrī}

The writing of the Satsangijivanam is mentioned again in part 4, in anticipation of the actual event. This part of the Satsangijivanam forestalls Swaminarayana's demise in a chapter on his secret resolve $(4,24)$. The text narrates about Swaminarayana's thoughts and intentions; and what on the literary level appears as the technique of the omniscient narrator, implies for the historian that Swaminarayana must at some point have told Satānanda about these intentions. The following is a summary of the contents of chapter 4,24:

16 He is referred to as "Suvrata's master"; this reminds the readers or the audience that they are listening to Suvrata's recital of the Satsangijīvanam, not to Śatānanda himself.

17 For a survey of the contents of the Satsangijivanam, see above, footnote 7. Altogether Satānanda is mentioned by name 30 times.

18 (Śrī-)Hari is how the Satsangijīvanam generally refers to Swaminarayana.

19 harināa lekhitāny așța sacchāstrāṇi tadagratạ | śatānando mahābuddhị śodhayām āsa cā̃njasā || 3,2.29 |

ya idam vidadhe prītya harilìlopabṛ̣hitam | satsañgijivanam ramyaṃ jīiātum harisevinām || 3,2.30 | 
Śrī-Hari recollects the motive of his incarnation: In the Kali-period adharma and vices had increased and dharma had deteriorated. Gods and sages were afflicted and the earth was unable to bear the burden of sinners. After having taken human birth due to the curse of Durvāsas, he destroyed evils and established dharma and devotion. Monks, gods and ascetics were delighted. The people of the four castes worshipped him, but they end up without any support after his disappearance. He wishes to support his followers in three ways (4,24.1-8): (1) Construction of the temples for installing his images, (2) appointment of a religious teacher (guru) from Dharma's family to increase devotion (cf. SSJ 4,40 f.); (3) composition of a book by Satānanda dealing with his life and works, i. e. the Satsangijīvanam. The purport of the Satsangijivanam is said to serve as the source-text containing the principles of all authoritative texts. After that (so Swaminarayana's thoughts continue) he will return to his abode (dhāman) (4,24.10-14). ${ }^{20}$ Then Śrī-Hari causes the scribes to copy (lekhayām $\bar{a} s a)$ authoritative texts. ${ }^{21}$

From the point of view of narrative technique this is an anticipating reference. Writing the Satsangijivanam falls under the measures taken to ensure the thriving of the movement after Swaminarayana's death. Since part 4 narrates about the construction of temples (first resolve) and the appointment of Ācāryas (ch. 4,40, realization of the second resolve) it seems plausible to read SSJ 4,43-44 as an account of the realization of the third resolve. These chapters relate the writing of the Sikṣāpatrī, not of the Satsangijīvanam.

To continue the summary, the account about the writing of Śikșāpatrī is embedded in reports about listening to recitations of the Bhāgavatapurāna. On the next day Śrī-Hari thinks about writing down a document (patrikā) to instruct dharma to his devotees of all regions so that after his departure they can practice

20 kārayitvā mandirāṇi tatra svapratimā aham | sthāpayeya tatas tāś ca seviṣyante hi mānavāḥ || 4,24.10| svadharme vartamānānām pumsām tatsevanād iha | siddhim eșyati sarveșāṃ puruṣārthacatușțayam || 4,24.11 | bhaktimārgasya puștyarthaṃ mantradīkșā apy apekșyate | ato dharmānvaye śuddhe gurutām sthāpayeya ca || 4,24.12 | dharmajñānaviraktīnām bhakteś cāvagamāya tu | granthaṃ kartā śatānando maccaritropabrṃhitam || 4,24.13 | siddhāntam sarvaśāstrāṇāṃ tena jñāsyanti macchritāḥ| evam eva tataḥ kṛtvā yāyām dhāma svakam bhuvạ̣ || 4,24.14 |

21 suvrata uvāca: sa evam gūạhasaṃkalpo nivasaṃs tatra pattane | lekhayām āsa sarvāṇi sacchāstrāṇi sulekhakaị̣ || 4,24.15 | I.e. texts like the Bhāgavatapurāṇa etc. (according to Śukānanda). 
it just according to his intention (4,43.18-21). He tells his attendant ${ }^{22}$ to bring a paper, ink-pot and pen (lekhinī) and writes the Sikșāpatrī, the essence of all authoritative texts (v. 22-24). ${ }^{23}$

What follows as chapter 4,44 is the Sanskrit text of the Sikșāpatrī comprising 212 verses. Swaminarayana mentions himself by name (Sahajānanda) and writes in first person (likhämi). He characterizes the text as a summary of the prescriptions of the dharma which all of his followers should obey; he is contemplating Śri-Kṛṣna with Rādhā and Lakṣmī in Vaḍatāla and writes the Śikșāpatrī for all his followers who live in different regions. He blesses his two (adopted) sons, celibates like Mukundānanda etc., householders like Mayarāma etc., married women, widows, and monks like Muktānanda etc., because they protect devotedly their dharma according to the authoritative texts. The Śikșāpatrī brings benefit to all beings. Those who observe the good conduct of the authoritative texts will get happiness, but the evil-minded people who fail to observe it will get misery. His disciples should follow it carefully (v. 1-10). ${ }^{24}$

22 The commentator Śukānanda says that this was Śukānanda, i.e. himself, which is a verification of Śatānanda's report by an independent witness.

23 aparāhṇe tatah svāmī vijanastho hitaṃ nụnạm | cintayan patrikām tebhyo likhitum niścikāya sạ̣ || 4,43.18 |

sakaleșv api deśeșu dharmaśikṣārthapatrikām |

likhāmi tena madbhaktā vartișyante tathaiva hi || 4,43.19|

mamāśayo yādriśo 'sti tādriśạ̣ cāpi te 'khilāh |

tayaivāvagamișyanti bhavișyanty apy asaṃśayāḥ || 4,43.20 |

antarhite mayi bhuvo madīyānām ca sarvaśah |

sphuțamadvākyarūpā sā bhavitry ālambanaṃ bhuvi || 4,43.21 |

evam vicārya dharmātmā kākudam khațikām ca sạ̣ |

ānayām āsa bhṛtyena lekhinīm ca suśobhanām || 4,43.22 |

sacchāstrāṇām sa sarveșāṃ sāram ākrṣya saddhiyā |

lilekha patrikām svāmī saddharmaṃ sthāpayan bhuvi || 4,43.23 |

ūrau dakșe pațtakam kākudasya |

krtvā dhṛtvā vāmadoșnā natāsyaḥ |

dakṣe pānau lekhinị̄ kuñcitāgre |

bibhrat patrị̄ so 'likhad bhūmipettham || 4,43.24 |

24 vāme yasya sthitā rādhā śrīs ca yasyāsti vakșasi |

ṿ̣ndāvanavihāram tam śrīkṛṣnam hṛdi cintaye || 4,44.1 |

likhāmi sahajānandasvāmī sarvān nijāśritān |

nānādeśasthitān śikṣāpatrị̣̄ vṛttālayasthitaḥ || 4,44.2 |

bhrātro rāmapratāpecchārāmayor dharmajanmanoh $\mid$

yāv ayodhyāprasādākhyaraghuvīrābhidhau sutau || 4,44.3 |

mukundānandamukhyāś ca naișțikā brahmacāriṇah |

grhasthāś ca mayārāmabhațtâadyā ye madāśrayāḥ || 4,44.4 |

sadhavā vidhavā yoṣa yāś ca macchișyatām gatāḥ |

muktānandādayo ye syụ̣ sādhavaś cākhilā api || 4,44.5 | 
He repeats this characterization of the Sikșāpatrī at its end (4,44.203-204): he has written down in short the essence of all authoritative texts; his followers may see details from those texts. His followers should behave according to the Śikșāpatrī, otherwise they will be considered as expelled. They should read or listen to it daily (v. 205-210). Eventually, the writing is unambiguously dated (v. 211): The Śikșāpatrī is written on the $5^{\text {th }}$ day called Vasantapañcamī of bright Māgha in VS 1882, i. e. 1825 A.D. The chapter ends with a benedictory stanza praying to Śrī-Kṛ̣̣na to bestow blessings. ${ }^{25}$

At the beginning of the next chapter, Satānanda's text supplies further details about the spread of this quoted text $(4,45.1-4):{ }^{26}$ After writing down

svadharmarakṣikā me taị̣ sarvair vācyāḥ sadāśișaḥ|

śrīmannārāyaṇasmṛtyā sahitāḥ śāstrasaṃmatāḥ || 4,44.6 |

ekāgreṇaiva manasā patrīlekhaḥ sahetukaḥ |

avadhāryo 'yam akhilaị̣ sarvajīvahitāvahaḥ || 4,44.7 |

ye pālayanti manujāh sacchāstrapratipāditān |

sadācārān sadā te 'tra paratra ca mahāsukhāh || 4,44.8 |

tān ullanghya vartante ye tu svairam kubuddhayah |

ta ihāmutra ca mahal labhante kaștam eva hi || 4,44.9 |

ato bhavadbhir macchișyaiḥ sāvadhānatayākhilaị |

prityaitām anusrttyaiva vartitavyam nirantaram || 4,44.10 |

25 iti saṃkṣepato dharmāḥ sarveșām likhitā mayā |

sāmpradāyikagranthebhyo jñeya eșām tu vistarah || 4,44.203 |

sacchāstrāṇām samuddhṛtya sarveșām sāram ātmanā |

patrīyam likhitā n⿳亠̣ṇām abhīștaphaladāyinī || 4,44.204 |

imām eva tato nityam anusrtya mamāśritaih |

yatātmabhir vartitavyaṃ na tu svairam kadācana || 4,44.205 |

vartișyante ya ittham hi puruṣa yoṣitas tathā |

te dharmādicaturvargasiddhị̣ prāpsyanti niścitam || 4,44.206 |

nettham ya ācarișyanti te tv asmatsampradāyatah |

bahirbhūtā iti jñeyam strīpumsaị sāmpradāyikaih || 4,44.207 |

śikṣāpatryāḥ pratidinam pāṭho 'syā madupāśritaih |

kartavyo 'nakșarajñais tu śravanam kāryam ādarāt || 4,44.208|

vaktrabhāve tu pujaiva kāryāsyāḥ prativāsaram |

madrūpam iti madvāṇi mānyeyam paramādarāt || 4,44.209 |

yuktāya saṃpadā daivyā dātavyeyam tu patrikā |

āsuryā sampadāẹhyāya pumse deyā na karhicit || 4,44.210|

vikramārkaśakasyābde netrāștavasubhūmite |

vasantādyadine śikṣāpatrīyaṃ likhitā mayā || 4,44.211 |

nijāśritānāṃ sakalārtihantā |

sadharmabhakter avanaṃ vidhātā |

dātā sukhānāṃ manasepsitānām |

tanotu kṛ̣ṇo 'khilamañgalam nạ || 4,44.212 |

26 suvrata uvāca: likhitvā patrikām ittham tasyāś ca pratimāșțakam |

sādhubhị̣ kārayitvāsau praișayat kakubho 'șta sạ̣ || 4,45.1 | 
the Śikṣāpatrī and telling the monks to write eight copies of it, Śrī-Hari sends the copies to the devotees in eight directions. Recognizing him as Kṛ̣na the devotees make their own copy and behave accordingly. After sending the copies, Śrī-Hari, surrounded by some of his devotees, goes to Ahmedabad (śrinagara).

There is no doubt that Swaminarayana is depicted as the author of the Sikșāpatrī; he is writing the original manuscript with his own hand. It is neither mentioned in which language he wrote nor which literary form he chose (prose or verses).

\section{4 Śatānanda as author of the Śikṣāpatrī}

To recapitulate: If interpreted as historical evidence, the episode reported in SSJ 4,24 and 4,43-44 (summarized in the previous section) about authorship and origin of Śikșāpatrī is straightforward: In the Satsañgijīvanam as a work authored by Śatānanda, the Śikșāpatrī is inserted ${ }^{27}$ as a quoted text; its author is not Śatānanda, but Swaminarayana (i. e., Sahajānanda).

But the origin of Satsangijīvanam and of the Sikșāpatrī it contains is told again at the end of part $5 .^{28}$ Chapter 56 introduces, for the first time, Śatānanda as somebody who poses questions to Swaminarayana and motivates instruction about a specific topic. The Satsangijīvanam here becomes autobiographical. The subject matter inquired about is yoga. Satānanda refers to the fact that he is among those people who experienced samādhi spontaneously, i.e., without yogic training, but induced by Swaminarayana. This is the only statement by Satānanda about himself in first person. Probably the event refers to the meeting in Badarìka (5,56.1-7). ${ }^{29}$

tatra tatra ca tāṃ prāpya bhaktāḥ prāpur mudạ̣ parām |

kṛtvā tatpratimām sarve pṛthak pṛthag adhārayan || 4,45.2 |

taduktarītyā sarve ca svādhikārānusārataḥ |

avartanta ca tạ̣ bhejur jānantạ̣ kṛșnam eva te || 4,45.3 |

patrikām preșayitvātha bhaktaih katipayair vṛtah |

harị śrīnagaram bhūyo jagāmānandayan nijān || 4,45.4 |

27 On 4,44.1 the commentary Bhāvaprabodhini notes that Śikșāpatrī is here "joined" (samyojyate) as chapter 44 of the Satsangijīvanam by Satānanda-Muni. The terminology suggests the independent existence of Śikșāpatrī but also the identity of the text written by Swaminarayana with the wording included in the Satsangijivanam.

28 Part 5 deals mainly with the dharma of various groups of society, interspersed with chapters on the installation of images in temples (see above, footnote 7).

29 suvrata uvāca: kṛṣnetarapadārtheșu rucihīnasya sarvathā | dharmādipracchake 'thāsìt puṃsi prītir harer nụpa || 5,56.1| 
Nine chapters further $(5,66)$, i. e., after citing what Swaminarayana had to say about yoga, Śatānanda reminds Swaminarayana of the boon which he had received at Badarìka: As Śrī-Hari had promised ${ }^{30}$ he should allow him to compose a work on Siri-Hari's life and deeds. Swaminarayana answers by bestowing the knowledge of past, present and future and he permits Śatānanda to write a work which will be a support for his followers after his disappearance. ${ }^{31}$ Śatānanda should stay in Gopīnātha's temple and render first the Śikșāpatrī in verses of Anușțubh meter. Śatānanda-Muni is pleased and Śrī-Hari retires to his residence. The concluding verse of the chapter tells that Śatānanda-Muni, considering ŚrīHari's command as an auspicious time, starts rendering the Śikṣāpatrī in verses $(5,66.25-35) .^{32}$

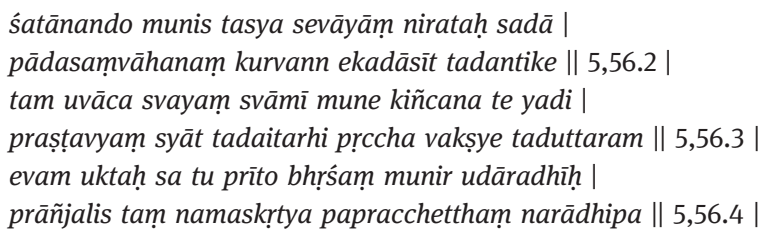

śatānanda uvāca: sāngam yogam ahạ̣ svāmin boddhum icchāmi tattvatạ̣ |

tvatta eva hi sarvajñāt sevanīyāc ca yogibhih || 5,56.5 |

mayā tu tvatprasādena yoginām api durlabhāḥ |

samādhisiddhị̣ prāptāsti vinā sādhanasampadam || 5,56.6 |

tathāpi lakṣaṇādīni yogaśāstrānusārataḥ |

vivitsāmy añgiyogasya tadañgānām ca sarvaśạ || 5,56.7

30 See SSJ 1,3, and above, Section 2.

31 This refers to the second of the secret intentions from 4,24.

32 śatānanda uvāca: prasanno yadi me svāmims tarhi tvam kṛpayādya hi | manoratham ciratnam me sampūurayitum arhasi || 5,66.25 |

tvaccaritragrantham aham cikirșāmi jagadguro | tad ājñām dehi me pūrvam bhavatāsti pratiśrutam || 5,66.26 |

saphalas tena bhavitā vidyābhyāsaśramo mama |

ity abhișțam hi me dehi bhaktābhișțtaprado 'si hi || 5,66.27 |

ity arthitah sa muninā premabhaktena dhimatā |

prasannạ̣ prāha taṃ yogin kuru granthaṃ svavāñchitam || 5,66.28 |

yathāśrutam yathādṛ̦țam caritram mama varnaya |

jñānam traikālikaṃ buddhau bhavaty eva tavānagha || 5,66.29 |

manaḥsthān apy abhiprāyān sarveșām vetsyasi dhruvam |

na te tv aviditam kiñcid bhavitātipriyo 'si me || 5,66.30 |

antarhite mayi bhuvo macchritānāṃ nụnām mune |

tvatkṛto grantha evātra bhavișyaty āśrayo mahān || 5,66.31 |

śikṣāpatrīm mallikhitām grathānādau tvam añjasā |

padyair ānuștubhair eva mahāgrantham tatah kuru || 5,66.32 |

vijane hi sthirā buddhị̣ syād atạ̣ krṣṇamandire |

vāsocitāsti kuțy ekā tatraiva nivaser mune || 5,66.33 | 
As historical information about the authorship of the text of the Sikṣāpatrī (which forms ch. 4,44 of the Satsangijivanam), this passage is indeed crucial for the argument of this paper. The relevant verses in translation read:

28cd. Graciously he said to him: "Yogin, make the book which you desire to make.

29. Describe my life and actions (caritram) as you have heard about it and seen it. In your mind (buddhi) exists the knowledge about past, present and future, o sinless one.

30. You shall certainly know also the intentions that are in the mind of everybody; nothing will remain unknown to you. You are extremely dear to me.

31. Once I have disappeared from this world, the book made by you shall be a great support for people who have taken refuge to me, o sage.

32. At first you shall straightaway string together (compose) the Śikṣāpatrī ("letter of instruction") that was written by myself, exclusively in anuștubh verses; then you shall make the large book.

33. The mind is stable only in a lonely place; therefore a single room in the Kṛna-temple is adequate as residence; you should reside there only, o sage."

34. (Suvrata said:) Thus addressed by Hari, the sage became even more pleased. He bowed before him and went to his own residence, o king.

35. The sage acknowledged that Hari's command was an auspicious occasion (muhūrta), took residence in a lovely room in the Krṣna-temple and then attentively composed the letter of instruction.

This means that in 1828 Satānanda had not started writing the Satsangijivvanam. Chapter 5,67 is very specific in narrating that he began the work with what is now chapter 44 of the $4^{\text {th }}$ part: Suvrata relates that from the $13^{\text {th }}$ day called "Dhanatrayodaśî"33 till the $2^{\text {nd }}$ day called "Yamadvitīyā"34 Śatānanda-Muni renders the Śikṣāpatrī in 212 verses; then he writes a commentary on it; after completing it on the $5^{\text {th }}$ day of bright Mārgaśīrșa (sahas) he submits it to Śrī-Hari in the assembly. Śrī-Hari is satisfied, appreciates him and bestows blessings by putting his hands on his head. On Śrī-Hari's command Nityānanda-Muni reads the Śikșāpatrî ${ }^{-35}$ in the assembly (5,67.1-8). ${ }^{36}$

suvrata uvāca: evam uktaḥ sa harịnā muniḥ pritataro 'bhavat |

tạ̣ praṇamya nijāvāsam upeyāya narādhipa || 5,66.34 |

ajñā harer eva śubham muhūrtam |

vidan sa krṣṇālayaramyakuțyām |

kṛtvā svavāsaṃ ca tadaiva śikșā- |

patrīm munir granthitum udyato 'bhūt || 5,66.35 |

33 Of dark Āśvina VS 1885 (1828 AD) (Śukānanda).

34 Of bright Kārttika.

35 Its Sanskrit version in verses.

36 suvrata uvāca: trayodaśī dhanādyāsīt tadānị̄ nṛpasattama| śikṣāpatrị̣̄ samārebhe sa tasyām granthitum munị̣ || 5,67.1| 
Śrī-Nārāyaṇa-Muni says that the followers, after the daily obligations, should sit in Svastika posture and recite it slowly understanding its meaning in the morning or at night (5,67.9-12). ${ }^{37}$ The devotees accept his words. Śrī-Hari allows Satānanda-Muni to compose the great work. After acquiring omniscience from Śrī-Hari he composes a chapter and reads it in the presence of Śrī-Hari and monks like Śukānanda etc. Śrī-Hari is satisfied (5,67.13-19). ${ }^{38}$

The text continues by relating further recitations of the Bhāgavatapurāna and about miracles attributed to the temple images. Thus one and a half years

pūrṇā yamadvitīyāyām sā krtā tena saddhiyā |

ślokāḥ śatadvayaṃ tasyā āsaṃś ca dvādaśottaram || 5,67.2 |

tataḥ sa bhagavatprītyai tasyāṣ țîkām ca śobhanām |

arebhe tāṃ sahomāse pañcamyāṃ ca samāpayat || 5,67.3 |

tasyām eva tithau rājann aparāhṇe samārpayat |

haraye munibhịh sākam upavișțāya saṃsadi || 5,67.4 |

sațīkām patrikāṃ svīyām dịșțā tāṃ saṃtutoṣa sạ̣ |

praśaṃsāṃ bahudhā cakre śatānandasya saṃsadi || 5,67.5 |

yāvān madīyo 'bhiprāya āsìt tāvān aśeșatah |

atrānìto 'sty aneneti munīn bhaktāṃś ca so 'vadat || 5,67.6 |

prityā dadau svakaṇțhasthām śatānandāya sa srajam |

karadvayaṃ cātimudā dadhau tacchirasi prabhuh || 5,67.7 |

tatas tāṃ vācayām āsa nityānandena saṃsadi |

harir bhaktāś ca munayah śrutvā tāọ jahrșur nṛpa || 5,67.8|

37 tatạ̣ prāha hariḥ sarvān bhaktān śṛ̣utākhilāḥ |

ye syur madīyās tair eșā pāṭhyā śravyāthavānvaham || 5,67.9 |

prāg eva bhojanān nityam śucibhị̣ svastikāsanam |

samāsthitair iyam pāṭyā tato bhojyam anāpadi || 5,67.10 |

divānukūlyābhāve tu niši nityavidhim nijam |

kṛtvaikatra nișadyaiva pațhanīyeyam ādarāt || 5,67.11 |

yathaitadarthasphuranam hṛdi svasya bhavet tathā |

śanaih sphuțākșaram pāṭ̂ā nityam eva madāśritaih || 5,67.12 |

38 iti śrutvā harer vākyam sarve bhaktajanās tadā |

evam eva karișyāmo vayam ity ūcur ānatāh $\| 5,67.13 \mid$

tato harị̣ śatānandaṃ prāha svābhisțtam uttamam |

kuru grantham mahābuddhe samartho 'si hi tatkrtau ||5,67.14|

krṣnnaprasādalabdhaiva buddhis te 'stīti bhāti nah |

anyathā madabhiprāyam evam vaktum kṣameta kah ||5,67.15|

sa ity ukto bhagavatā tam praṇamya nijāśramam |

ayayau durlabham devaị samprāptas tadanugraham $\| 5,67.16 \mid$

hariprasādasamprāptasārvajñayaḥ so 'tha yogirāṭ |

campāṣașțhyām samārebhe idam satsañgijìvanam \|5,67.17|

ekaikam ca prakaraṇam kṛtvā sampūrṇam îsvaram |

tam eva śrāvayām āsa nijāvāsasthitam munih $\| 5,67.18 \mid$

sa śuśrāvādarāt sākaṃ nityaṃ svāntikavāsibhị̣ |

śukānandādimunibhis tena tușțo 'bhavad bhṛśam ||5,67.19| 
pass $(5,67.19-40)$. This reads like an indication of how long it took him to write the Satsangijīvanam.

The beginning of the next chapter (SSJ 5,68) tells that all of these events and details are linked with the impending departure of Swaminarayana. Suvrata's report reviews Swaminarayana's achievements. The circumstances justify his departure. To summarize:

At the end of the night of the 9th day of bright Jyeștha Śrī-Hari ponders again about the completion of all deeds in human form: non-righteous teachers and kings are refuted; greed etc. are eradicated from people's hearts through the authoritative texts and through his own power; truth, non-stealing etc. have been established on earth; devotion accompanied by dharma, knowledge and detachment is propagated; Dharma, Mūrti, Uddhava and other sages are freed from Durvāsas' curse; knowledge of Brahman, Yogic techniques, sacrifices without violence, faith in gods, Brahmins and holy places are strengthened; doctrines of Kaulas and non-believers are refuted; images of Nara-Nārāyaṇa etc. are installed in temples; ranks of the religious masters and initiation ceremony are established; Sikșāpatrī is composed; dharmas of men, women and monks etc., yoga with eight steps and regulations for vows and festivals are imparted; Satānanda-Muni's work for the benefit of mankind comes close to completion (samāptaprāyah). He should now bestow peace on the affectionate devotees and return to his abode $(5,68.1-19) .^{39}$

39 suvrata uvāca: navamyām atha suklāyām jyeșțhasya sa niśātyaye | vicāram akarod bhūya ātmanātmani bhūpate || 5,68.1 |

mayā dhṛto 'vatāro 'yaṃ yadartham tad aśeșatah | kāryam kṛtam bhūtale 'tra na kiñcid avaśeșitam || 5,68.2 |

adhārmikā gurvasurā dharmasādhudruho nṛpāḥ | pratāpena mayā svasya parāstāḥ sakalā api || 5,68.3 | adharmavaṃśyā lobherșyākāmakrodhādayo 'pi ca| sacchāstrasvapratāpābhyām utkhātā hṛdayān nṛ̣nām || 5,68.4 | satyāsteyabrahmacaryadayādyā dharmavamiśajāḥ | sthāpitā hṛdaye n⿳̣̣nām mayā samyag dharātale || 5,68.5 | svadharmajñānavairāgyayuktā bhaktiś ca sarvataḥ | pravartitā pratigṛhaṃ nụnāṃ niḥśreyasāya ca || 5,68.6| dharmo mūrtiś coddhavaś ca durvāsaḥśāpato mayā| mocitāś carṣayah prāyo mucyamānās tathetare || 5,68.7 | brahmavidyāś ca sakalā nānāyogakalās tathā| pravartitāḥ pratijanam ahimssāś ca makhā bhuvi || 5,68.8 | devabrāhmaṇatīrthānāṃ nigamānām satāṃ tathā | pravartitā mānyatā ca sacchāstrāṇām ca sarvathā || 5,68.9 | asacchāstrasya kaulāder nāstikānām matasya ca | vidhāya khaṇdanam dharmah sthāpito 'tra sanātanah || 5,68.10 | vidhāpya mandirāṇy atra svāśritānām sukhāya ca | 
A few points from this account deserve further attention: Swaminarayana's words to Satānanda which formulate the task of writing the Satsangijivanam and of beginning with the Sikșāpatrī (5,66.28-33) use the verb grath for the literary activity demanded. This generally means "to compose, to string together”. The apposition "in anuștubh verses" could be a syntactical characterization of the Sikșāpatrī as written by Swaminarayana or of how Śatānanda should compose the text. There is no explicit mention of "translation", but it cannot be excluded that Swaminarayana's text was not only not in anușțubh verses but also not in Sanskrit. When the narrator (Suvrata) relates that Satānanda executes the demand, he uses the same verb (grath).

We are also told that he worked on the Śikșāpatrī for five days; if Śatānanda only had to copy 212 verses, this emphasis on the brevity of the period would be incomprehensible. If he reformulated a prose Sanskrit text the contradiction would be less patent; if he actually transcreated the Sanskrit verses from a Gujarati (or Hindi) original, the emphasis would make sense.

The Sikșāpatrī as discussed in SSJ 4,44 ends with a date: It was written in 1825 in Vṛttālaya. There is no mention here of an intervention by Śatānanda as either redactor or translator. The redaction of Śikṣāpatrī is also dated: 1828 (SSJ 5,67.1); the Śikșāpatrī thus existed for three years before Śatānanda translated or transcreated it into Sanskrit verses. At that time the Satsangijivanam was "nearing completion". 40

\footnotetext{
sthāpitā mūrtayaḥ svasya naranārāyaṇādayaḥ || 5,68.11 | bhaktimārgapravṛttyartham dharmavaṃśyadvijeșu ca | acāryatā sthāpitātha dīkṣārītih pravartitā || 5,68.12 | sadācārapravṛttyarthaṃ svāśriteșu pravartitā | sarvasacchāstrasāro hi śikșāpatrī mayā bhuvi || 5,68.13| varṇināṃ naișțhikānām ca gṛhịnām yoṣitām mayā | sādhūnām itareșām ca dharmāḥ samyan் nirūpitāḥ || 5,68.14 | vratotsavānām sarveșāṃ vidhiś cokto mayākhilaḥ | vidhir aștāñgayogasya sakalo 'pi nirūpitah || 5,68.15 | kalau janișyamānāạm śatānandena dehinām | uddhṛtyai kārito granthaḥ samāptaprāya eva sạ̣ || 5,68.16 | evam yat sveba kartavyam tat sarvam hi krtam mayā | atạ param svadhāmaiva gantavyam adhunā bhuvaḥ || 5,68.17 | kimtv adyaiva tirobhūte mayi sarve madāśritāh | mayy evātisnehabhājo dehān hāsyanti tat kṣaṇam || 5,68.18 | ato madviraham soḍhum akșamānām hi sarvathā | teșāṃ śāntim vidhāyaiva yāyāṃ dhāma nijam param || 5,68.19|
}

40 It could not have been finished since it includes the events around Swaminarayana's demise, to occur later than the narrated event. 


\section{Conclusion, questions and prospects}

To summarize the evidence collected from the Satsangijīvanam: There are two accounts about the origin of Sikșāpatrī. In the first one Swaminarayana is described as writing the text; in the second one Satānanda is told to transform this text into Sanskrit verses. Thus, if the specificity of the version inserted in the Satsangijivvanam is said to consist in being in Sanskrit and in anușthubh verses, the original is likely to be different in both regards and may have been written in Gujarati and in prose. It would follow that the Sikșāpatrī which followers of Swaminarayana recite is a text written by Satānanda who did so upon the authority of Swaminarayana. This observation concerns the literary form of the text, not its contents; and even if the literary form is not authored by Swaminarayana, he explicitly approved of it. Pursuing the differentiation of authorship and authority in the reception history of the Śikșāpatrī in the Swaminarayana Movement, i. e., in commentaries and exegetical literature, might be revealing about the importance of textual traditions and their functions.

The questions raised on account of the origin of the Sikșāpatrī in the Satsangijīvanam about the authorship of the received text of the Siikșāpatrī concern the historical value of all information in the Satsangijivanam. Episodes with mythological character (involving demons, etc.) may lead to the question as to whether and where to draw a line between history and mythology or legend? And, more importantly, how to draw it. A comparison with other biographical sources and accounts would impose itself. There are independent witnesses of some events (Bishop Heber's report, the architectural witnesses of the temples he had built, other texts, etc.).

The Satsangijīvanam reports that eight copies of the original Śikșāpatrī were distributed. Where are these eight copies? There is obviously the possibility (or even probability) that the original might still exist. The eight copies (see SSJ 45,45.1-3) were perhaps not all copied directly from the original; they might represent a small stemma. The search for these manuscripts (and, if successful, their preservation) is a research task which outsiders cannot achieve. The account in the Satsangijivanam justifies an appeal to the authorities of all the branches and dioceses of the Swaminarayana-Movement to undertake this task. To compare them with the Śikṣāpatrī as contained in the Satsangijīvanam would be of great text historical interest.

There is no defined process of canonization institutionalized in the movement. The authorization of Śatānanda by Swaminarayana cannot be repeated and lives on in the consensus of the community of followers. Changes are not a 
priori excluded unless authorization and authorship are confused or wrongly identified with canonization of texts.

The evidence of the Satsangijīvanam provokes such questions. Answering them is a task for further historical research.

Acknowledgements: The article is based on Peter Schreiner's presentation at the international conference entitled "Sahajanand Swami and the Swaminarayan Sampraday: Historical, Social and Cultural Perspective” (New Delhi, 1-4 August 2013), organized by the B.A.P.S. Swaminarayan Research Institute. It results from research on the Satsangijivanam carried out in collaboration with Jaydev A. Jani (M.S. University of Baroda) during a research project at the University of Zürich (Switzerland) between 1992 and 1994. The funding by the Swiss National Research Foundation (Schweizer National Fonds) is gratefully acknowledged.

\section{Bibliography of quoted references}

Śrīsatsamgijīivanam: Śrīsatānandamuniviracitam : Śrīśukānandamuniviracitayā hetusaṃjñayā țīkayā, Sa. Dha. Dhu. Ācāryaśrīvihārilālamahārājaviracitayā bhāvaprabodhinyākhyayā vyākhyayā ca sametam : Vṛttālayapāṭhaśālāpradhānapaṇ̣̂itena embār Krș̣namācāryeṇa saṃśodhitam Sa. dha. dhu. ācārya śrī Ajendra Prasādamahārājājñayā sāraṃgapura mandiramukhyāmātyena Śrī Kațhāri Nārāyaṇa Municaraṇadāsena mumbayyāṃ sārikākhyamudrạ̣ālaye mudrāpya prākāśyaṃ nītam. Saṃvat 2046; san 1987.

Williams, Raymond Brady (1984): A New Face of Hinduism : The Swaminarayan Religion. Cambridge: Cambridge University Press.

Williams, Raymond Brady/Trivedi, Yogi (eds.) (in press): Swaminarayan Hinduism: Tradition, Adaptation and Identity. New Delhi: Oxford University Press. 